\title{
Problems and Prospects of Legal Regulation of Regional Trade and Economic Cooperation within the Framework of the Shanghai Cooperation Organization (An Example of the Krasnodar Krai)
}

\author{
Dashin A. V. ${ }^{1}$, Petrov I. V. ${ }^{1}$, Simatova E. L. ${ }^{1}$ \& Shapoval O. V. ${ }^{1}$ \\ ${ }^{1}$ Southern Institute, Krasnodar, Russia \\ Correspondence: Dashin A. V., Southern Institute, Stavropolskaya street, 216, Krasnodar 350040, Russia. E-mail: \\ russia@prescopus.com
}

Received: October 14, 2017

Accepted: March 14, $2018 \quad$ Online Published: March 28, 2018

doi:10.5539/jpl.v11n2p1

URL: https://doi.org/10.5539/jpl.v11n2p1

\begin{abstract}
The article analyzes the legal regulation of trade and economic cooperation in the territory of the SCO member states. Based on the analysis of legal acts regulating these legal relations both internationally and nationally, the authors make a number of proposals for improving the regulatory framework, placing particular emphasis on the regulation of economic relations between the subjects of the Russian Federation and other regions of foreign states (using the example of Krasnodar Krai).
\end{abstract}

Keywords: Shanghai Cooperation Organization, foreign economic activity, international treaties, unification of legal norms, trade and economic cooperation, foreign trade missions

\section{Introduction}

Today, in the socio-political, economic and legal space, the problems of using regional resources aimed at maximizing the opportunities of a single constituent entity of the Russian Federation are becoming increasingly urgent. This is due to the need for a comprehensive development of both the internal infrastructure and individual industries that are traditional to the region.

Issues of financial and infrastructural support for small regional businesses and expansion of cooperation between regional companies of the Shanghai Cooperation Organization member countries (hereinafter referred to as SCO) became the subject of discussion at the First Small Business Forum of the regions of the SCO member states (September 2015, Ufa, Russia). Therefore, it becomes obvious that the further development of both the separately taken region and the country as a whole should take into account the activities of the SCO (in the context of economic cooperation) and requires adequate legal regulation of the ongoing processes.

Despite the rapid development of the investment policy in the Kuban region, as well as the growing international trade cooperation between Krasnodar entrepreneurs and their foreign partners, a serious obstacle to the implementation of these relations is the ambiguity of the existing legislation in this area. It is not only about the existence of significant contradictions between various normative legal acts at the national level. As part of the SCO activities, there is no basic document regulating private-legal relations in the field of international commercial contracts and investment relations, despite the fact that in Art. 3 SCO Charter - the provision of favorable conditions for trade and investment, free movement of goods, capital, services and technologies (Meeting of the legislation of the Russian Federation, 2002) is stated as one of the areas of cooperation. Proceeding from the strategic tasks of the functioning of the SCO as an organization that preaches closer cooperation and integration, including on economic issues and at the regional level, the situation needs to be changed radically. It requires the adoption of a conceptual agreement containing detailed standards, including unified concepts and principles for the implementation of foreign economic activity.

\section{Results}

\subsection{Unification of Legal Standards Regulating Trade-Economic Cooperation within the Framework of the SCO}

It should be recognized that the process of unification of legal norms in the field of trade and economic cooperation is more confident in comparison with other areas of private legal relations, for example, in the sphere of marriage and family or real property relations. This is confirmed not only by the long-term successful 
experience of using a significant number of universal multilateral conventions (the UN Convention on Contracts for the International Sale of Goods is the most vivid example of the foregoing). This should also include the active use of Lex Mercatoria as a result of the work of various international organizations to systematize and publish a set of customs of international business turnover. Such archives as INCOTERMS or the Principles of UNIDROIT International Commercial Contracts are very popular for many reasons, such as the high prestige of the specialists who develop these documents, the simplicity and clarity of the presentation, the supranational character, etc. These, as well as some other reasons, explain the appearance of drafts of new documents designed to regulate international trade relations (Simatova, 2015).

It is the multiplicity of trade customs, their varying understanding in different countries, which hampered the effectiveness of international trade, which prompted the International Chamber of Commerce to unify and publish collections of international trade practices. Thus, the above-mentioned "Incoterms" give a unified interpretation of several bases for the supply of goods within the framework of contracts for the sale of goods and constitute a source of information on customs in this field. This series can be supplemented:

-Unified rules and customs on documentary letters of credit (last edition - 1993);

-Unified rules on collection (last edition - 1995);

-Unified rules on contractual guarantees (last edition - 1993);

-Unified rules for guarantees on first request (last edition - 1992);

-Codified ICC and repeatedly revised with it, in accordance with changes in international trade.

It is necessary to take into account the unique norm-setting experience of the European Union with regard to the unification of legal norms. In the context of the problem under consideration, however, it is necessary to talk about the unification of conflicts, not material norms, which does not detract from the value of such legal acts, since in some cases it is the conflict mode that plays the leading role in overcoming the contradictions of international legal regulation. The series of regulations of the European Parliament and of the Council of the European Union - the so-called RIMs 1, 2, 3, aimed at regulating various types of private legal relations complicated by a foreign element, mainly of a mandatory nature, underscores the importance of using the conflict method when it comes to regional cooperation that has both similarities in the use of legal mechanisms, and a significant difference.

Such an attempt (quite successful, judging by the number of references to the document in the Russian judicial practice) was made in the territory of the CIS, of course, this is, of course, the CIS Convention on Legal Aid and Legal Relations in Civil, Family and Criminal Cases of 1993 (Collected Legislation of the Russian Federation, 1995) which in Part IV regulates the property relations, namely the property right, the form of the transaction, the power of attorney, the rights and obligations of the parties to the transaction, compensation for damages and statute of limitations. And it is a question of the unification of conflict, and not material norms.

It should be taken into account that of the 8 SCO member countries, 5 are CIS members (Russia, Kazakhstan, Kyrgyzstan, Tajikistan, Uzbekistan), also bearing in mind Belarus as an observer state and Azerbaijan and Armenia as dialogue partners. That is why it is possible to say with certainty that the prerequisites for the creation of the above basic, conceptual document containing unified (both material and conflict) norms and regulating trade and economic cooperation within the $\mathrm{SCO}$ framework exist and give higher chances for its fairly light and rapid development and successful use.

\subsection{Regional Aspect}

One of the most important tools for implementing international cooperation is the development of economic relations between the subjects of the Russian Federation and other regions of foreign states. In Art. 1 of the Federal Law of 4 January 1999 No. 4-FZ (Edited on July 13, 2015) "On the coordination of international and foreign economic relations of the subjects of the Russian Federation" (Collection of Legislation of the Russian Federation, 1999) enshrines the right of the subjects of the Russian Federation to implement international and foreign economic relations with the subjects of foreign federal states, administrative-territorial entities of foreign states, as well as to participate in the activities of international organizations within the relevant bodies.

Similar provisions are contained in the Federal Law "On the Basics of State Regulation of Foreign Trade Activity" (Meeting of the legislation of the Russian Federation, 2003), where the powers of the state authorities of the subjects of the Russian Federation in the field of foreign trade activities are fixed, including negotiation and conclusion of agreements (Article 8).

The main criteria for the investment attractiveness of the Krasnodar Krai are: a fairly successful geopolitical 
location between Europe and Asia; there is a direct access to international sea routes; agro-climatic potential; recreational potential, ensuring the development of virtually all types of tourism and recreation industry. In the Krasnodar Krai, the International Investment Forum Sochi has held annually, which is by right considered the largest platform for a large-scale presentation and discussion of investment projects.

An appropriate regulatory framework has been created in Krasnodar Krai, there are tax incentives and mechanisms to assist investors. The law "On the state stimulation of investment activity in the Krasnodar Krai" (Law of the Krasnodar Territory of July 2, 2004), which allows creating the most favorable conditions for all willing subjects to invest in various sectors of the economy of the region.

In 2015-16 years a number of interregional agreements on cooperation in the Krasnodar region with one of the participants of the SCO - Kazakhstan. Investors from Kazakhstan account for $28.2 \%$ of the total investment. The main spheres of foreign capital investment are transport, food industry, trade and catering, forestry, woodworking industry, communications. So, at the XII Forum of Interregional Cooperation of Russia and Kazakhstan, held in Sochi, agreements for the supply of dairy products from the Krasnodar Krai to Kazakhstan (Kaloria, Krasnodar) and rice seeds (Kuban Rice Research Institute) were signed.

At the same time, the formation of conceptual solutions in this area is required. It seems that the main trends in the field of foreign economic cooperation of the Krasnodar Krai with partners from the SCO member states should be: the establishment of foreign trade missions in the territory of the Krasnodar Krai and relevant Russian offices in the territory of foreign countries, the conclusion of agreements on trade and economic cooperation, the adoption of special laws at the federal and regional levels. Such activities of the regions do not yet have a single normative international base and do not have unified institutions and mechanisms for cooperation.

Currently, there are no special agreements between the Krasnodar Krai and the SCO countries. On March 20, 2015 the delegation of the Republic of Tajikistan headed by Ambassador Extraordinary and Plenipotentiary of the Republic of Tajikistan to Russia - Mr. Sattorov, visited the Krasnodar Krai. Within the framework of the visit, a meeting and negotiations were held with the leadership of the Representative Office of the Ministry of Foreign Affairs of the Russian Federation in Krasnodar, the Honorary Consul of the Republic of Tajikistan in Krasnodar. As a result of the visit, the parties agreed to start preparing an Agreement between the Administration of the Krasnodar Region and the Government of the Republic of Tajikistan on trade, economic and cultural cooperation, the draft Agreement is currently undergoing the signing procedure.

From November 22 to November 26, 2015, there was a delegation of the People's Republic of China in Krasnodar Krai. Within the framework of the visit, the delegation visited large industrial enterprises, such as "The Kuban Combine of Wall Materials", "The Krasnodar Compressor Plant", "The Agricultural Machinery plant CLAAS", and also they took part in the International Agro-Industrial Exhibition "Yugagro". During the visit, there was a meeting of the Krasnodar Krai Governor Ms. Kondratieva with representatives of the Embassy of the People's Republic of China in the Russian Federation and the Chinese Committee for the Promotion of International Trade, they discussed the development of cooperation in the field of industry and agriculture. Guests from China were introduced to priority investment projects. In particular, potential investors were presented with the sites designated for the construction of eight industrial parks - specially prepared fully constructed investment sites, which allow to launch production lines in the shortest time and minimize the costs for investors. As a result, a partnership agreement was signed between the Chairman of the Union "Chamber of Commerce and Industry of the Krasnodar Krai" Mr. Tkachenko and the General Representative of the Chinese Committee for the Promotion of International Trade - Xu Jinli.

Next, let us look into the legal regulation of the trade missions functioning. The main functions of foreign representations are to promote the goods and services produced in the constituent entities of the Russian Federation in the external market, search for potential investors, and provide information to regional participants in trade and economic activities.

In addition to the Federal Law on the Coordination of International and Foreign Economic Relations of the Subjects of the Russian Federation, the activities of foreign missions are regulated by international and intergovernmental agreements, the Constitution of the Russian Federation, federal laws, Presidential Decree No. 1478 of November 8, 2011 "On the coordinating role of the Ministry of Foreign Affairs of the Russian Federation in conducting a unified foreign policy line of the Russian Federation" (Collected Legislation of the Russian Federation, 2011), laws of the subjects of the Russian Federation.

The right of the constituent entities of the Russian Federation to open their representative offices outside the Russian Federation and authorize the opening of foreign representative offices on the territory of the relevant constituent entity of the Russian Federation is regulated by the provisions of the Federal Law "On Coordination 
of International and External Economic Relations of the Subjects of the Russian Federation" (Article 10). The opening of foreign missions in the territory of a certain subject of the Russian Federation, in addition to the agreement with the Russian Ministry of Foreign Affairs, requires an appropriate agreement between the state authority of the subject of the Russian Federation and the authorized body of the subject of a foreign state (authorized administrative and territorial entity). Foreign missions are directly subordinate to the foreign ministries of their countries. Usually, the mentioned representative offices appear in reciprocity conditions and demonstrate close contacts of Russian and foreign regions in the sphere of exchange of goods, works and services.

As a rule, the subjects of the Russian Federation open their trade missions in a foreign country, entrusting them with the duty to realize the interests of the region on economic cooperation. In cases of opening representative offices abroad, subjects of the Russian Federation must obtain the consent of the Russian Foreign Ministry. Direct procedure for obtaining such consent is not regulated, it is determined by the Ministry of Foreign Affairs of Russia in each case independently.

The Federal Law "On the Basics of State Regulation of Foreign Trade Activity" stipulates that the opening of a representative office in foreign countries is related to the implementation of the formation and implementation of regional programs; information support of this activity on the territory of the region; the creation of insurance and collateral funds in the field of foreign trade in the territory of the region belongs to the competence of the state authorities of the subject of the Russian Federation (Article 8).

It should be taken into account that the representative offices of the constituent entities of the Russian Federation in the territories of foreign states, as well as foreign representative offices operating in the territory of a certain region of the Russian Federation do not have the status of diplomatic missions and do not exercise consular functions or diplomatic functions.

The procedure for the operation of trade missions, their powers are regulated by the subjects of the Russian Federation at their own discretion through the adoption of regulatory legal acts, since unified rules in this sphere are absent. In this regard, it is required to develop, first of all, a federal law that defines the legal status of a trade mission, on the basis of which the subjects of the Russian Federation can build their own regulatory legal acts.

In the Civil Code of the Russian Federation, the legal status of the representation is defined in only one article 55, according to which, the representation is a separate subdivision of a legal entity located outside its location, representing the interests of this legal entity and carrying out their protection. At the same time, it is clearly stipulated that the representative offices are not considered legal entities, they are transferred property to them by the legal entity that created them, and the activity is carried out on the basis of the provisions approved by it.

Representations are indicated in the unified state register of legal entities. In addition, it is stipulated that the heads of the mission are directly appointed by a legal entity and act on the basis of a power of attorney.

In some cases, trade representation is characterized as a form of mediation. Considering the trade representation of a subject of the Russian Federation not as a structural unit, but as an activity, it can be said that this is a representative's activity aimed at promoting goods, works, and services of the relevant region in the territory of a foreign state. With a sufficient degree of conventionality, the norms of the Civil Code of the Russian Federation on commercial representation are applicable to these relations. In particular, commercial representation of various parties in the transaction is permissible, which is not applicable to a commercial representation.

In his dissertation research, Z.E. Tigiev considers commercial representations of the Russian Federation and the subjects of the Russian Federation as independent legal entities that have the right to take their actions in the entrepreneurial sphere on their own behalf, conclude contracts on their behalf and perform other legal actions. In turn, the trade mission of the Russian Federation abroad is a state body that ensures foreign economic interests of the Russian Federation in the host country and operates under the direct political leadership of the Russian Ambassador abroad. The trade mission has a seal with the image of the State Emblem of the Russian Federation, presses, stamps and letterheads necessary to carry out its activities, can open settlement and other accounts with credit institutions in the manner and under the conditions governed by the legislation of the Russian Federation and the legislation of the host country (Tigiev, 2010).

We believe that here the arguments can be the availability of a separate representative property from the trade mission, transferred by the owner (RF, subject of the Russian Federation), the opportunity to bear independent responsibility, conclude deals on its own behalf and act as a plaintiff or defendant in court.

\section{Conclusion}

Summing up, we can say that at present it is necessary to create foreign trade missions in the territory of the 
Krasnodar Krai and relevant Russian offices in the Krai of foreign states participating in the SCO, conclude agreements on trade and economic cooperation, and adopt special laws at the federal and regional levels. Such activities of the regions do not yet have a single normative international base and do not have unified institutions and mechanisms for cooperation. In this regard, it is advisable to adopt a federal law that defines the legal status of a trade representation, on the basis of which the subjects of the Russian Federation can build their own regulatory legal acts. Before the adoption of such legal acts, it is possible to amend Art. 2 of the Federal Law "On the Fundamentals of State Regulation of Foreign Trade Activities", the definitions "trade representation", "trade representation of the Russian Federation", "trade representation of the subject of the Russian Federation", stipulating that trade representations of the Russian Federation and the constituent entities of the Federation are independent legal entities.

\section{Conflict of Interest}

The authors confirm that the presented data do not contain a conflict of interest.

\section{Acknowledgment}

The work was prepared within the framework of the scientific project No. 17-13-23017 "Problems and prospects for the legal regulation of regional trade and economic cooperation within the framework of the Shanghai Cooperation Organization (based on the example of the Krasnodar Krai)" supported by Russian Foundation for basic research and Krasnodar Krai administration.

\section{References}

Collected Legislation of the Russian Federation. (1995). Convention on Legal Assistance and Legal Relations in Civil, Family and Criminal Cases (concluded in Minsk on 22.01.1993) (entered into force on 19.05.1994, for the Russian Federation on 10.12.1994) (as amended on 28.03.1997). Collected Legislation of the Russian Federation, (17), Art. 1472.

Collected Legislation of the Russian Federation. (2011). On the coordinating role of the Ministry of Foreign Affairs of the Russian Federation in the conduct of a unified foreign policy of the Russian Federation: Decree No. 1478 of the President of the Russian Federation of December 8, 2011. № 46. Art. 6477.

Collection of Legislation of the Russian Federation. (1999). On the coordination of international and economic relations of the constituent entities of the Russian Federation: Federal Law No. 4-FZ of January 4, 1999 (as amended on July 13, 2015). № 2. Art. 231.

Law of the Krasnodar Territory of July 2. (2004). On the state stimulation of investment activities in the Krasnodar Territory. Information Bulletin of the Law of the Krasnodar Territory. July 26, 2004, No. 19 (Part I).

Meeting of the legislation of the Russian Federation. (2003). On the fundamentals of state regulation of foreign trade: Federal Law No. 164-FZ of December 8, 2003 (as amended on July 13, 2015). № 50. Art. 4850.

Meeting of the legislation of the Russian Federation. (2006). Charter of the Shanghai Cooperation Organization: adopted in St. Petersburg on 07.06. 2002. No. 43. Art. 4417.

Simatova, E. L. (2015). Trends and Prospects for the Development of lex mercatoria in Private International Law. Contemporary Law, (8), S. 131-135.

Tigiev, Z. E. (2010). Legal status of the trade mission under the legislation of the Russian Federation: the author's abstract. Jurid. Sciences. M. 2. C. 17.

\section{Copyrights}

Copyright for this article is retained by the author(s), with first publication rights granted to the journal.

This is an open-access article distributed under the terms and conditions of the Creative Commons Attribution license (http://creativecommons.org/licenses/by/4.0/). 